\title{
Geochemistry of shoshonites from the Upper Keewatin Assemblage, western Wabigoon Belt, Superior Province, Canada
}

\author{
Osamu UJIKE* and Alan M. GoodwIN** \\ *Department of Earth Sciences, Toyama University, Gofuku 3190, Toyama 930-8555, \\ Japan \\ **Department of Geology, Earth Sciences Centre, University of Toronto, Toronto, \\ M5S 3B1 Canada
}

\begin{abstract}
2.7 Ga shoshonites occur in the Upper Keewatin Assemblage of the Shoal Lake-Lake of the Woods area in the northwestern part of the late Archean Wabigoon Belt, Superior Province, Canada. They are enriched both in large-ion lithophile elements $(\mathrm{K}, \mathrm{Rb}, \mathrm{Sr}, \mathrm{Ba}$ and $\mathrm{Th})$ and compatible elements $(\mathrm{Mg}, \mathrm{Ni}$ and $\mathrm{Cr}$ ). Their incompatible element abundance patterns exhibit a negative Ta anomaly and high $\mathrm{La} / \mathrm{Yb}$ and $\mathrm{Sr} / \mathrm{Y}$ ratios, similar to adakitic volcanic rocks in the same area. We suggest that the shoshonite magmas were formed by partial melting of a mantle source enriched by contemporaneous adakitic magmas derived by melting of subducted oceanic crust. We further speculate on the origin of Timiskaming alkaline volcanic rocks, located $1100 \mathrm{~km}$ to the east in the Abitibi Greenstone Belt, Superior Province, the archetypal example of late Archean alkaline magmatism. It seems probable that the mantle sources of Timiskaming alkaline rocks also were metasomatized by adakitic magmas, but that this source enrichment occurred 20-30 m.y. prior to the Timiskaming magmatism.
\end{abstract}

\section{Introduction}

Shoshonites and shoshonitic alkaline rocks occur rarely in Archean terrains and may be restricted to Superior Province of the Canadian Shield (e.g., Blichert-Toft et al., 1996). It has been argued that Superior Province shoshonites represent late or last-stage magmatic products in volcanic arc settings and that they were derived, based on geochemical analogy to modern shoshonites, from mantle sources metasomatized by subduction -related fluids rich in large-ion lithophile elements (LILE) (e.g., Brooks et al., 1982; Dostal and Mueller, 1992).

The greenstone belt succession in the Shoal LakeLake of the Woods area (SL in Fig. 1), ca. $20 \mathrm{~km}$ in stratigraphic thickness, is divided into three assemblages, in ascending order, Lower Keewatin (2743-2732 Ma), Upper Keewatin (2732-2719 Ma), both $\sim 10 \mathrm{~km}$ thick, and the thin, unconformably overlying Electrum ( $\sim 2700 \mathrm{Ma}$ ) Assemblage; the three consisting respectively of dominant mafic tholeiitic metavolcanic rocks,

O. Ujike, ujike@sci.toyama-u.ac.jp Corresponding author assorted calc-alkaline to tholeiitic metavolcanic rocks, and mainly turbiditic metasediments (Ayer and Davis, 1997; Ayer and Dostal, 2000). Shoshonitic metavolcanic rocks have been identified in both the Electrum and Upper Keewatin Assemblages. In the latter, we found shoshonites in the Monument Bay Group, located at about mid-thickness in the assemblage. The occurrence of shoshonites in the mid-later development stages of an Archean greenstone belt appears to be rare, and may provide useful clues to the general problem of Archean shoshonitic magmatism. We will first study the geochemistry and genesis of these Upper Keewatin shoshonites, followed by genetic discussions, using existing geochemical data, on the origin of the slightly younger, Timiskaming alkaline volcanic rocks ( $\mathrm{T}$ in Fig. 1, 2680-2670 Ma), Abitibi Greenstone Belt. The Timiskaming volcanism is a well-documented, archetypal example of late Archean alkaline magmatism (e.g., Blichert-Toft et al., 1996).

\section{Samples and analytical}

Fifty volcanic rocks, either lava flows or pyroclastic 


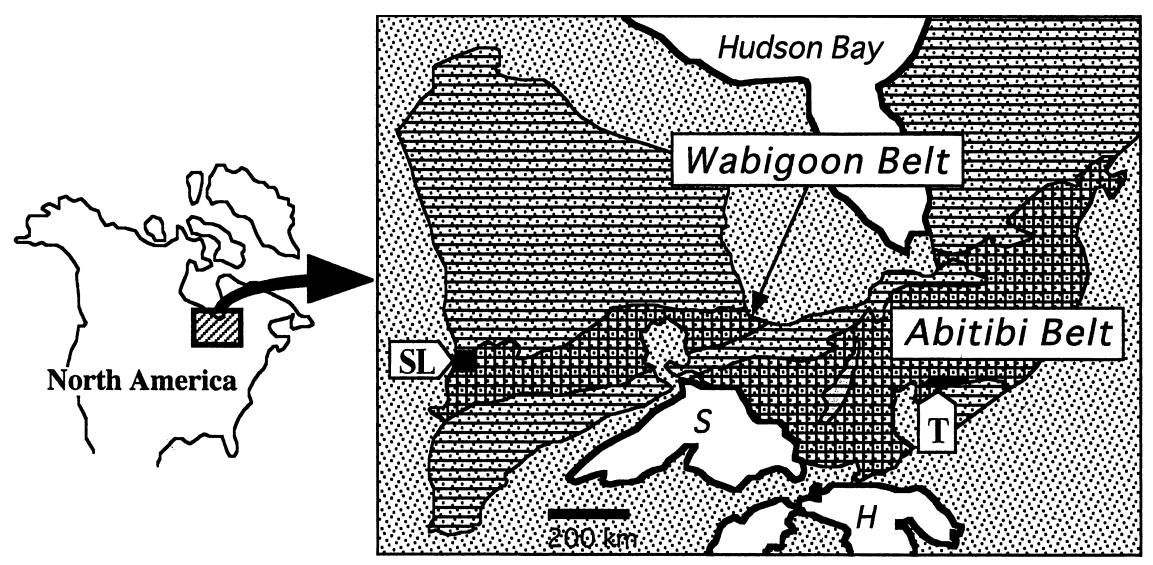

Figure 1. Locality of the study area. SL stands for Shoal Lake-Lake of the Woods area, T for Timiskaming assemblage, $\mathrm{S}$ for Lake Superior, and $\mathrm{H}$ for Lake Huron. Horizontal hatch area is Superior Province. Cross hatch areas are Wabigoon and Abitibi belts.

units, were sampled from the Shoal Lake-Lake of the Woods area, at the northwestern corner of the Wabigoon Belt (SL in Fig. 1). They were analyzed for the normal major and 24 trace elements using X-ray fluorescence and neutron activation analysis techniques. The analytical equipment, procedures and precisions are as those described by Ujike and Goodwin (1987).

Among the $50 \mathrm{SL}$ samples, we found two shoshonites (K39, tuff-breccia; and K41, breccia) within a diverse stratigraphic succession of dominant subalkaline volcanic rocks of the Monument Bay Group, Upper Keewatin Assemblage (2720 Ma; Ayer and Dostal, 2000). The two other rock types in this assemblage are: (1) a suite of calc-alkaline andesitic to rhyolitic rocks having high $\mathrm{La} / \mathrm{Yb}$ and low $\mathrm{Yb}\left([\mathrm{La} / \mathrm{Yb}]_{\mathrm{N}} /[\mathrm{Yb}]_{\mathrm{N}}>\right.$ 1.0 , where []$_{\mathrm{N}}$ denotes chondrite normalized value after Taylor and Gorton, 1977), which are temporarily called high $-\mathrm{La} / \mathrm{Yb}$ rocks; and (2) subalkaline basaltic to dacitic rocks having relatively low $\mathrm{La} / \mathrm{Yb}$ and high $\mathrm{Yb}$ $\left([\mathrm{La} / \mathrm{Yb}]_{\mathrm{N}} /[\mathrm{Yb}]_{\mathrm{N}}<1.0\right)$, which are temporarily called low-to-moderate- $\mathrm{La} / \mathrm{Yb}$ rocks. We thereby geochemically divided the $50 \mathrm{SL}$ samples into three groups: 1) shoshonites, 2) high- $\mathrm{La} / \mathrm{Yb}$ rocks, and 3) low-tomoderate- $\mathrm{La} / \mathrm{Yb}$ rocks (Fig. 2).

Samples K39 and K41 (Table 1, and stars in Figs. 2-4), though not so illustrated, are high in $\mathrm{K}_{2} \mathrm{O}$ content and plot well within the shoshonite field of Ewart (1982) on a $\mathrm{K}_{2} \mathrm{O}-\mathrm{SiO}_{2}$ diagram. These two samples are classified respectively as basaltic trachyandesite and trachyandesite by TAS classification (Fig. 3a); they are further classified as shoshonite series rocks because they contain $\mathrm{K}_{2} \mathrm{O}>\mathrm{Na}_{2} \mathrm{O}-2.0$ (Le Maitre, 1989). Figure 3b, a discrimination diagram using immobile elements, supports the classification of samples K39 and K41 as trachytic in a broad sense. Furthermore, they tend to be richer in Th, a highly incompatible element rather resistant to secondary alteration processes (e.g., Condie et al., 1977), than Th contents of other Archean shoshonites from Abitibi Belt, Superior Province (Fig. 4). Thus, we consider that their present high alkali contents probably reflect primary magmatic composition of shoshonites. It is further noted that SL shoshonites are characterized by 1) moderately high $[\mathrm{La} / \mathrm{Yb}]_{\mathrm{N}}$ with 2 ) slightly positive to no $\mathrm{Eu}$ anomalies (Table 1), 3) distinct depletions in Ta relative to $\mathrm{Th}$ and $\mathrm{Ce}$ in a MORBnormalized elemental abundance pattern (Fig. 5), and 4) CIPW normative olivine, as long as we assume realistic oxidation state of iron (i.e., $\mathrm{Fe}^{2+}>\mathrm{Fe}^{3+}$ ).

The high- $\mathrm{La} / \mathrm{Yb}$ SL rocks are similar in incompatible element abundance patterns to the SL shoshonites (Fig. 5), but in contrast, are quartz-normative. These high-La/Yb SL samples mostly fall in the Archean tonalite-trondhjemite-granodiorite field in the $\mathrm{La} / \mathrm{Yb}-$ $\mathrm{Yb}$ diagram (Fig. 2a), in the adakite field in the $\mathrm{Sr} / \mathrm{Y}-\mathrm{Y}$ diagram (Fig. 2b), and in the andesite-dacite-rhyolite field in the alkali-silica and $\mathrm{Zr} / \mathrm{TiO}_{2}-\mathrm{SiO}_{2}$ diagrams (Fig. 3a, b). Their $\mathrm{MgO}$ contents tend to be higher, at a given $\mathrm{SiO}_{2}$ content, than that of both the low-tomoderate $-\mathrm{La} / \mathrm{Yb}$ rocks from the SL study area and Cenozoic adakites, and are distinctly higher than that of the a) adakitic glass inclusions in mantle xenoliths, b) experimentally produced adakitic melts, and c) Archean trondhjemites-tonalites-dacites (Fig. 3c).

Most of the low-to-moderate- $\mathrm{La} / \mathrm{Yb}$ SL rocks fall in the lower part or below the Post-Archean granitoids field in the $\mathrm{La} / \mathrm{Yb}-\mathrm{Yb}$ diagram (Fig. 2a). They also fall in the lower part of the island arc ADR (andesitedacite-rhyolite) field in the $\mathrm{Sr} / \mathrm{Y}-\mathrm{Y}$ diagram (Fig. 2b) as well as in the andesite-dacite-rhyolite field in the alkali-silica and $\mathrm{Zr} / \mathrm{TiO}_{2}-\mathrm{SiO}_{2}$ diagrams (Fig. 3). 

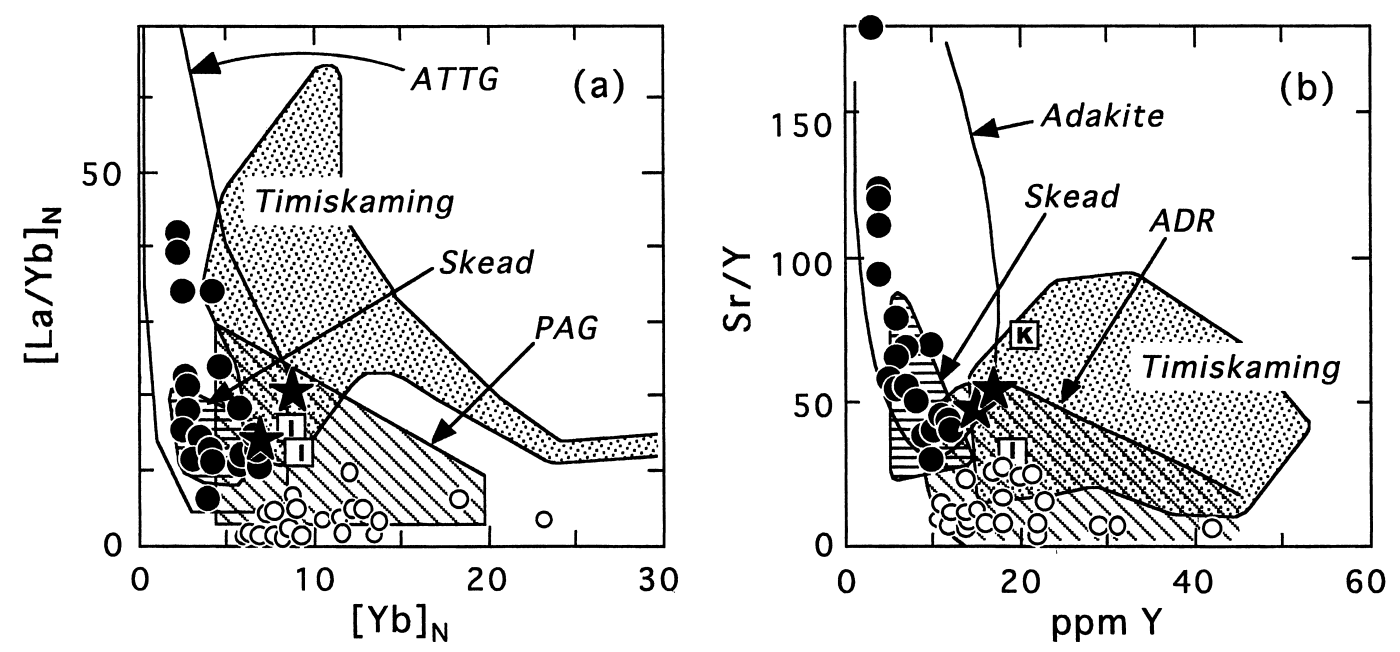

Figure 2. a) $[\mathrm{La} / \mathrm{Yb}]_{\mathrm{N}}-[\mathrm{Yb}]_{\mathrm{N}}$, and b) $\mathrm{Sr} / \mathrm{Y}-\mathrm{Y}$ diagrams for the examined samples and Cenozoic shoshonitic rocks. Symbols: star, shoshonite; solid circle, high-La/Yb (=adakitic) rocks; and open circle, low-to-moderate-La/Yb rocks; all from the SL study area. The boundary lines in 2a for ATTG (Archean tonalite-trondhjemite-granodiorite) and PAG (Post-Archean granitoids) are from Martin (1986), and in 2b for adakite and ADR (island arc andesite, dacite and rhyolite) are from Defant and Drummond (1990). The horizontally hatched fields (Skead) represent the compositional range of 15 volcanic rocks from the Archean Skead Group, Abitibi Belt (Capdevila et al., 1982) (see further below). The dotted areas in $2 \mathrm{a}$ and $\mathrm{b}$ represent the fields in which 46 Timiskaming alkaline volcanic rocks (Ben Othman et al., 1990; Capdevila et al., 1982; Kerrich and Watson, 1984; Ujike, 1985) are plotted. I in squares mark shoshonite from Iraya volcano, Batan Island, the Philippines (Maury et al., 1992; Sajona et al., 2000); K in square marks absarokite from Katamata volcano, Abu, southwest Japan (Kakubuchi et al., 2000), the latter lacking REE analysis.

They tend to be richer in compatible elements and poorer in incompatible elements (e.g., Fig. 4) than the other rock groups (Table 1). Among them, basalts generally show positive Eu anomalies, while most of the felsic rocks show negative Eu anomalies (Table 1).

\section{Discussion}

\section{Origin of the high-La/Yb rocks from the Upper Keewatin Assemblage}

Figure 2 suggests that the high- $\mathrm{La} / \mathrm{Yb}$ rocks may be effusive equivalents of Archean TTG suite plutonic rocks (Jahn et al., 1981; Martin, 1986), thereby also representing Archean analogues of Cenozoic adakites (Defant and Drummond, 1990; Martin, 1999; Defant and Kepezhinskas, 2001). Thus, we will call them adakitic rocks hereafter. Cenozoic adakite suites with high $\mathrm{MgO}$ are considered to be derived from magmas produced by interaction of partial melts of subducted oceanic crusts with a mantle wedge (e.g., Rapp et al., 1999; Martin, 1999; Smithies, 2000; Defant and Kepezhinskas, 2001). Mainly based on their high $\mathrm{MgO}$ content (Fig. 3c), we suggest that the western Wabigoon adakitic magmas were produced by an analogous process, and not by melting of the base of a thickened crust.

\section{Origin of shoshonites from the Upper Keewatin Assemblage}

Shoshonites from the Upper Keewatin Assemblage appear to be subduction related because volcanic rocks from intraplate and spreading plate boundary regions generally do not show such a distinct Ta depletion as they do in Figure 5 (e.g., Pearce, 1983). Similar arguments have been made for other Archean shoshonites in Superior Province: e.g., 1) Oxford Lake, Manitoba (Brooks et al., 1982) and 2) Chibougamau, Quebec (Dostal and Mueller, 1992). In both cases, the authors argue that magmas parental to these Archean shoshonites were derived by partial melting of a mantle wedge modified by LILE-rich fluid phases released from subducted oceanic crust. Furthermore, Dostal and Mueller (1992) have pointed out that Chibougamau shoshonites have affinities to the archetypal Timiskaming alkaline rocks, Abitibi Greenstone Belt, in geochemistry and hence in magmagenesis.

In the case of the studied samples, the close mutual similarity in incompatible element abundance patterns (Fig. 5a) combined with their occurrence in a single stratigraphic group (i.e., Monument Bay Group, Upper Keewatin Assemblage) suggests that the SL shoshonites and adakitic rocks may be genetically related. However, it is unlikely that the two groups are related by processes of crystallization differentiation and/or crustal 
Table 1. Chemical analyses of 5 representative samples from the SL area

\begin{tabular}{|c|c|c|c|c|c|}
\hline Sample & K39 & K41 & K40 & K9 & K144 \\
\hline \multicolumn{6}{|l|}{ (wt \%) } \\
\hline $\mathrm{SiO}_{2}$ & 55.65 & 53.08 & 50.87 & 69.68 & 70.65 \\
\hline $\mathrm{TiO}_{2}$ & 0.46 & 0.68 & 0.51 & 0.57 & 0.26 \\
\hline $\mathrm{Al}_{2} \mathrm{O}_{3}$ & 12.66 & 14.59 & 12.72 & 13.96 & 17.19 \\
\hline FeO.t & 7.66 & 8.19 & 11.75 & 5.23 & 1.71 \\
\hline $\mathrm{MnO}$ & 0.13 & 0.12 & 0.17 & 0.13 & 0.01 \\
\hline $\mathrm{MgO}$ & 6.74 & 7.40 & 11.66 & 1.54 & 1.23 \\
\hline $\mathrm{CaO}$ & 8.44 & 9.31 & 10.59 & 3.48 & 2.06 \\
\hline $\mathrm{Na}_{2} \mathrm{O}$ & 3.50 & 2.93 & 1.48 & 2.49 & 5.04 \\
\hline $\mathrm{K}_{2} \mathrm{O}$ & 3.80 & 2.97 & 0.00 & 2.80 & 1.69 \\
\hline $\mathrm{P}_{2} \mathrm{O}_{5}$ & 0.96 & 0.74 & 0.25 & 0.13 & 0.18 \\
\hline \multicolumn{6}{|l|}{$(\mathrm{ppm})$} \\
\hline $\mathrm{Cs}$ & 2.5 & 1.8 & $\mathrm{dl}$ & 1.7 & 1.2 \\
\hline $\mathrm{Rb}$ & 96 & 62 & $\mathrm{dl}$ & 70 & 38 \\
\hline $\mathrm{Ba}$ & 1140 & 1146 & 74 & 473 & 439 \\
\hline $\mathrm{Sr}$ & 709 & 921 & 155 & 213 & 537 \\
\hline Co & 33 & 35 & 57 & 6 & 17 \\
\hline $\mathrm{Ni}$ & 128 & 54 & 211 & 4 & 16 \\
\hline$Y$ & 15 & 17 & 11 & 31 & 3 \\
\hline $\mathrm{Sc}$ & 21.9 & 27.7 & 37.1 & 12.1 & 5.3 \\
\hline V & 161 & 210 & 237 & 26 & 81 \\
\hline $\mathrm{Cr}$ & 403 & 151 & 845 & 5 & 32 \\
\hline Th & 7.4 & 10.9 & 0.2 & 5.4 & 4.0 \\
\hline $\mathrm{U}$ & 1.6 & 2.2 & 0.3 & 1.3 & 1.0 \\
\hline $\mathrm{Hf}$ & 3.4 & 3.1 & 0.9 & 6.0 & 2.8 \\
\hline $\mathrm{Zr}$ & 112 & 122 & 28 & 273 & 92 \\
\hline $\mathrm{Ta}$ & 0.3 & 0.5 & 0.2 & 1.0 & 0.2 \\
\hline $\mathrm{La}$ & 31.3 & 57.1 & 2.46 & 35.0 & 28.1 \\
\hline $\mathrm{Ce}$ & 63.7 & 121 & 3.18 & 69.1 & 59.6 \\
\hline $\mathrm{Nd}$ & 33.4 & 55.9 & 2.92 & 30.3 & 21.7 \\
\hline $\mathrm{Sm}$ & 6.26 & 8.49 & 1.17 & 6.00 & 3.40 \\
\hline $\mathrm{Eu}$ & 1.70 & 2.67 & 0.75 & 1.58 & 1.14 \\
\hline $\mathrm{Tb}$ & 0.59 & 0.83 & 0.39 & 0.79 & 0.25 \\
\hline $\mathrm{Yb}$ & 1.42 & 1.81 & 1.72 & 3.82 & 0.47 \\
\hline $\mathrm{Lu}$ & 0.21 & 0.22 & 0.21 & 0.55 & 0.06 \\
\hline$[\mathrm{La} / \mathrm{Yb}]_{\mathrm{N}}$ & 14.6 & 20.8 & 0.90 & 6.1 & 39.5 \\
\hline $\mathrm{Eu} / \mathrm{Eu}^{*}$ & 1.0 & 1.2 & 1.6 & 0.87 & 1.4 \\
\hline
\end{tabular}

FeO.t, total $\mathrm{Fe}$ as $\mathrm{FeO}$. Major oxides recalculated to $100 \%$ volatile-free. K39 and K41, shoshonite; K40, low-La/Yb basalt; K9, moderate- $\mathrm{La} / \mathrm{Yb}$ dacite; and $\mathrm{K} 144$, adakitic rhyolite. dl, below the detection limit $(0.2 \mathrm{ppm}$ for Cs and $3 \mathrm{ppm}$ for $\mathrm{Rb}$ ). $\mathrm{Eu} / \mathrm{Eu}^{*}$, obtained by division of observed $\mathrm{Eu}$ content by $\mathrm{Eu}$ value estimated by straight line interpolation between $\mathrm{Sm}$ and $\mathrm{Tb}$ contents in chondrite-normalized REE patterns.

contamination because the adakitic rocks are poorer in incompatible elements (alkalis and $\mathrm{Th}$ ) at comparable levels of $\mathrm{SiO}_{2} \quad(\sim 55 \%)$ and compatible element $(\mathrm{Ni}$ $\sim 100-50 \mathrm{ppm}$ ) contents than the shoshonites (Figs. 3a and 4). Rather, the adakitic magmas were probably generated by partial melting of subducted oceanic crust with subsequent reaction of the melt with the upper mantle, as stated above. The lower $\mathrm{SiO}_{2}$ and higher $\mathrm{MgO}$ contents of the shoshonites (Fig. 3) may suggest that they had the same origin as the adakitic rocks, but with more intense interaction of the partial melts with

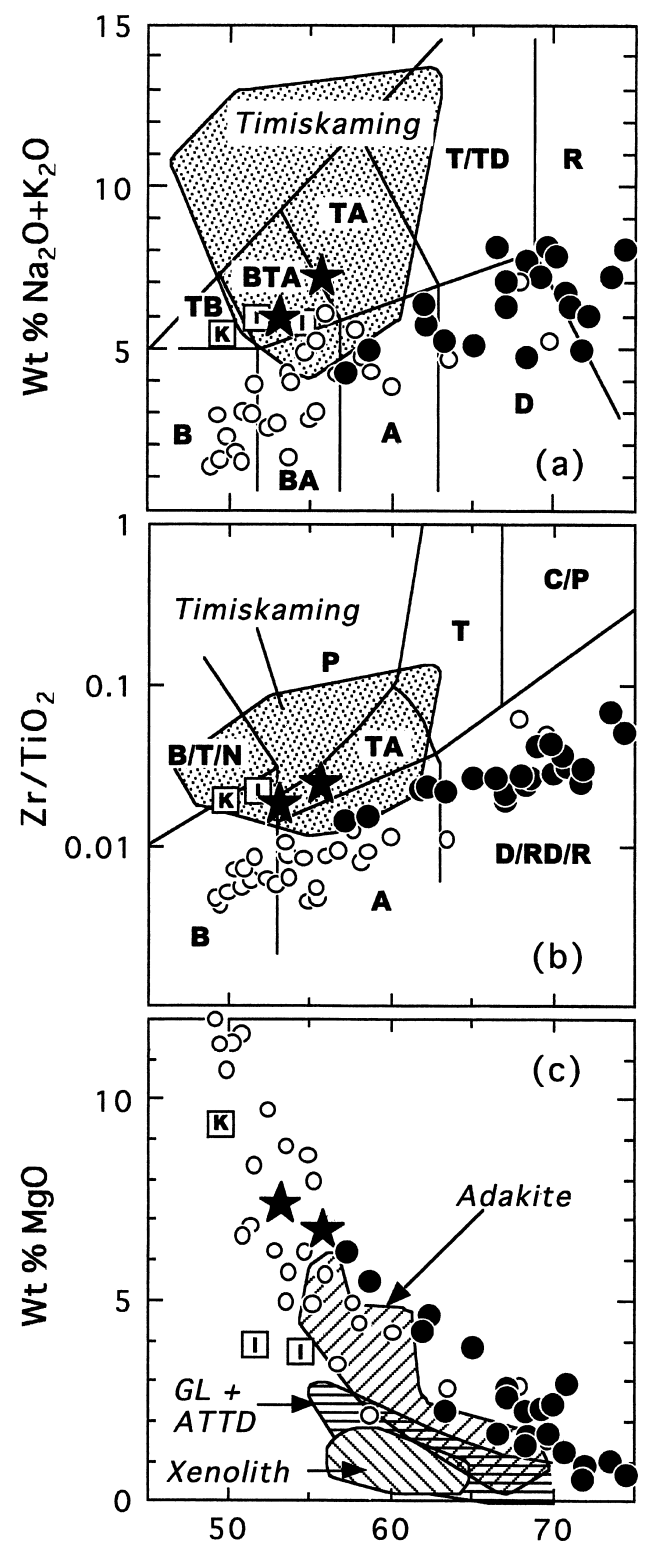

Figure 3. a) $\mathrm{Na}_{2} \mathrm{O}+\mathrm{K}_{2} \mathrm{O}-\mathrm{SiO}_{2}$, b) $\mathrm{Zr} / \mathrm{TiO}_{2}-\mathrm{SiO}_{2}$, and c) $\mathrm{MgO}-\mathrm{SiO}_{2}$ diagrams for the 50 samples from SL area and some Cenozoic shoshonitic rocks. Symbols and data sources are same as in Figure 2 except for Katamata absarokite with analysis from Tatsumi and Koyaguchi (1989). The fields marked by B (basalt), BA (basaltic andesite), A (andesite), D (dacite), R (rhyolite), TB (trachybasalt), BTA (basaltic trachyandesite), TA (trachyandesite) and T/TD (trachyte or trachydacite) in (a) are cited from Le Maitre (1989). The fields marked by B (alkaline or subalkaline basalt), A (andesite), D/RD/R (dacite, rhyodacite or rhyolite), $\mathrm{B} / \mathrm{T} / \mathrm{N}$ (basanite, trachybasanite or nephelinite), $\mathrm{P}$ (phonolite), TA (trachyandesite), $\mathrm{T}$ (trachyte) and $\mathrm{C} / \mathrm{P}$ (comendite or pantellerite) in (b) are from Winchester and Floyd (1977). The three fields in 3c respectively marked as Adakite, GL + ATTD (composite field for experimentally produced adakitic melts and Archean trondhjemites-tonalites-dacites), and Xenolith (adakitic glass inclusions in mantle xenoliths) are from Defant and Kepezhinskas (2001). 


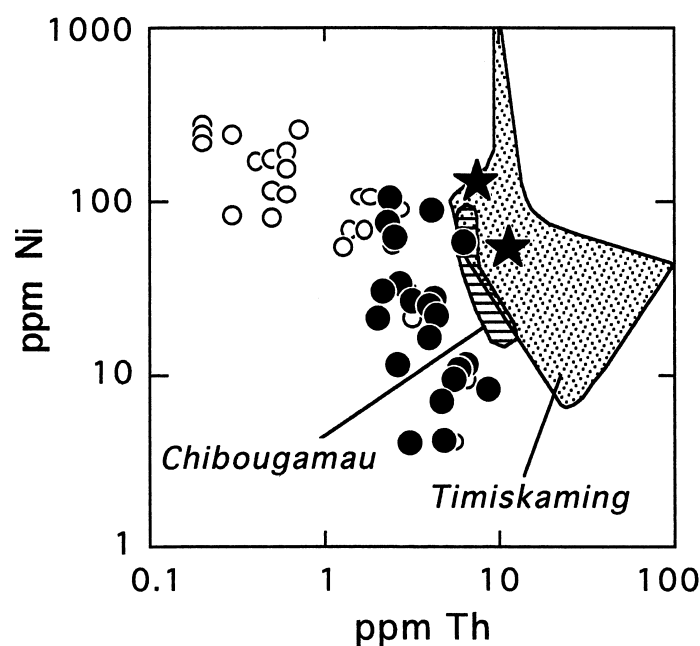

Figure 4. Ni-Th diagram for the $50 \mathrm{SL}$ samples and other selected Archean volcanic rocks. The field marked by Chibougamau represents Archean feldspar-phyric shoshonites from Chibougamau, Abitibi Belt cited from Dostal and Mueller (1992). Other symbols and data sources are as in Figure 2.

the mantle. If this is the case, it would be expected that the chemical compositions of the adakitic rocks and shoshonites form linear trends in variation diagrams. Actually, the shoshonites plot away from extensions of the adakitic trends in alkali-silica, $\mathrm{Zr} / \mathrm{TiO}_{2}-\mathrm{SiO}_{2}$ and compatible element-incompatible element diagrams (Figs. 3 and 4), indicating that these two groups are not related by different degrees of interaction between the melts and mantle in the same level.

On the other hand, the olivine-normative nature combined with high compatible element $(\mathrm{Mg}, \mathrm{Ni}$ and Cr) contents of the shoshonites (Table 1, Fig. 4) suggests their origin from ultramafic rocks. Thus, the shoshonite-adakite juxtaposition leads us to consider that the source of the shoshonitic magma involved mantle peridotite enriched by contemporaneous adakitic magmas. This model is similar to those proposed for other Archean shoshonites (e.g., Brooks et al., 1982; Dostal and Mueller, 1992) in that the source mantle was enriched by slab-derived material, but different from them in that the agent was melts as opposed to fluids. There is no conclusive proof that the mantle was enriched by adakitic magmas, but we would like to emphasize that Wyman et al. (2000) have stated that the upper mantle was metasomatized by adakitic magmas beneath the western Wabigoon Belt based on their finding of $\mathrm{Nb}_{-}$ enriched basalts from the Sturgeon Lake area, $\sim 300 \mathrm{~km}$ to the east. The $\mathrm{Nb}$-enriched basalt is a member of the "adakite metasomatic volcanic series" proposed by Defant and Kepezhinskas (2001).

Adakitic felsic melts derived from the subducted oceanic slab would have hybridized the overlying mantle peridotite, resulting in phlogopite-bearing mafic to ultramafic rocks (Wyllie and Sekine, 1982), depending on the amount of felsic melt involved. Recent melting experiments (Rapp et al., 1999) indicate that the ascending slab melts would have been fully consumed, via metasomatism, by the overlying mantle peridotite when the melt: rock ratio is small $(\leq 1: 1)$. The western Wabigoon upper mantle prior to, or where unaffected by, adakitic metasomatism would have been depleted, as suggested by the occurrence of basalts with $[\mathrm{La} / \mathrm{Yb}]_{\mathrm{N}}<1.0$ (e.g., K40 in Table 1). Taking these considerations into account, we performed model calculations regarding the origin of the shoshonites. An example of the results is shown in Figure 5. Such result indicates that the shoshonite composition can be reproduced by batch melting of a mantle enriched by adakitic rhyolite, at least in terms of overall incompatible element abundance patterns.

The close association of shoshonitic rocks (i.e., shoshonite or absarokite) and adakitic rocks is not restricted to the late Archean age, but is also reported from several Cenozoic volcanic areas as has been pointed out by Defant and Drummond (1990), though not always expressly stated. Pertinent areas include Batan Island, the Philippines (Sajona et al., 2000) and Abu volcano group in southwest Japan (Kakubuchi et al., 2000). Results of petrogenetic studies on these Cenozoic shoshonitic rocks are in accordance with our proposal.

Maury et al. (1992) have shown, based on model calculations on incompatible element compositions, that partial melting of a mantle xenolith metasomatized by an adakite magma could produce its host shoshonitic lava from Iraya volcano, Batan Island (Sajona et al., 2000: $I$ in square in Figs. 2 and 3). While on the basis of melting experiments, Tatsumi and Koyaguchi (1989) have suggested that an absarokite from Katamata ( $\mathrm{K}$ in square in Figs. 2 and 4), Abu volcano group, was generated from an enriched lherzolite. Incompatible element abundance patterns are analogous between the Katamata absarokite and an Abu adakite (Table 1 in Kakubuchi et al., 2000) though the absolute abundances are different. This geologic setting compares closely to that of the studied late Archean shoshonites and adakitic rocks. In summary we conclude that the studied western Wabigoon shoshonite magmas were probably derived from mantle sources enriched by adakitic magmas. 

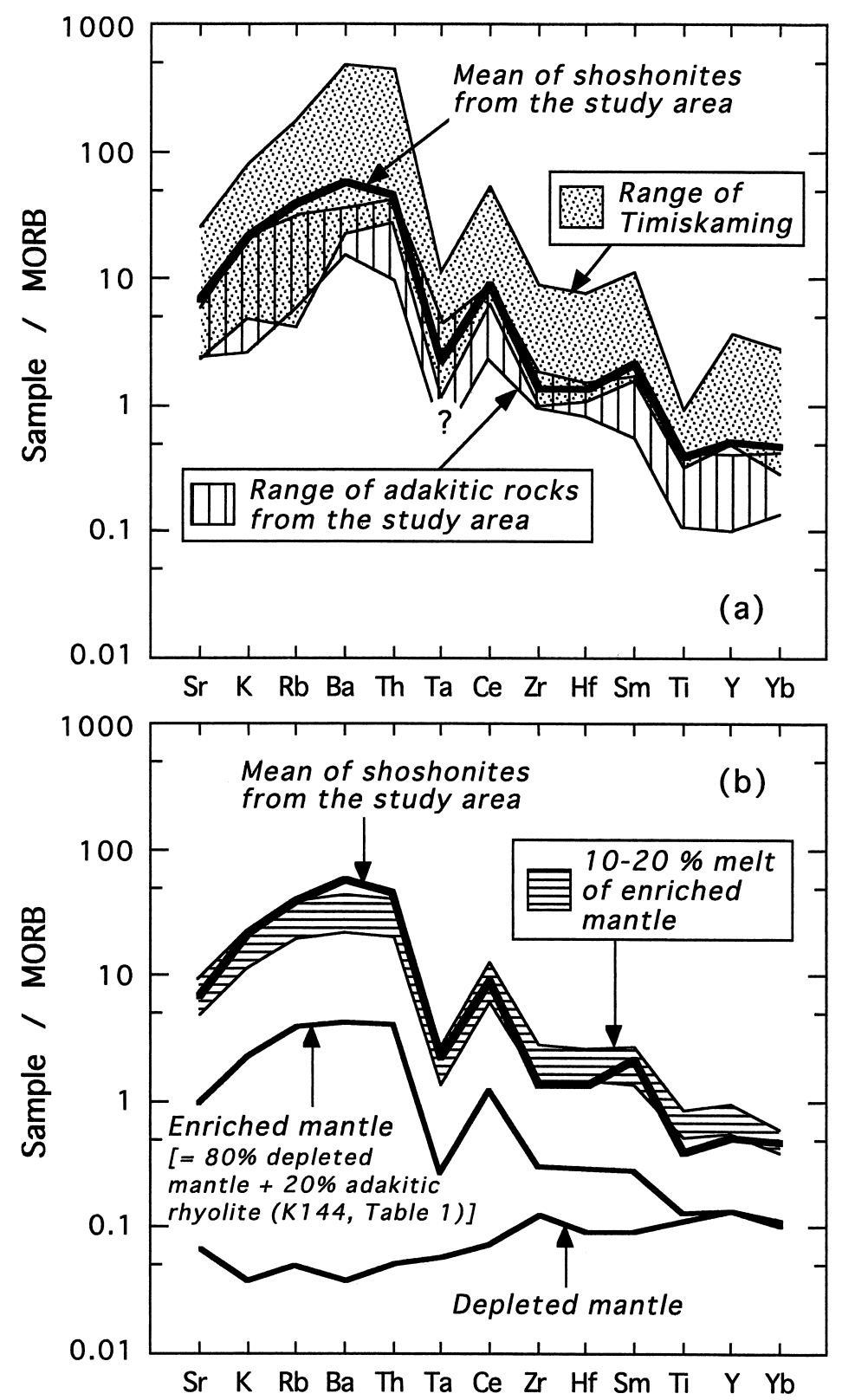

Figure 5. MORB-normalized incompatible element abundance patterns for a) shoshonites and adakites from the SL study area, and Timiskaming alkaline rocks from Abitibi Belt, and b) shoshonites from the SL study area and results of model calculations. MORB values are from Pearce et al. (1981). Data sources for Timiskaming alkaline volcanic rocks are as in Figure 2. A rhyolite (K148), exceptionally poor in incompatible elements (e.g., La $=7.2 \mathrm{ppm}$ and $\mathrm{Zr}=30 \mathrm{ppm}$ ), is excluded from the range of adakitic rocks. Question mark (?) in the figure is used for a point of which value was below the detection limit (0.2 ppm for Ta). Depleted mantle composition was taken from Yogodzinski et al. (1995), except for Rb, Zr, and Y which are from Wood et al. (1979). Enriched mantle is a mixture of the depleted mantle (80\%) with an adakitic rhyolite (20\%: K144 in Table 1). Partial melt compositions by an equilibrium melting model (Arth, 1976) leaves a harzburgite assemblage (olivine: orthopyroxene $=65: 35$ ). Partition coefficients used in the model calculation are largely from Kelemen et al. (1993) and run 1802 of Green et al. (2000), with some arbitrary values.

\section{Implications for the origin of Timiskaming alkaline magmas}

The above discussion leads us to consider that other shoshonitic-alkaline volcanic rocks in the Archean Superior Province may have originated through analo- gous processes. We here additionally speculate on the origin of the Timiskaming alkaline volcanic suite, Abitibi Greenstone Belt (Fig. 1) as representative of other shoshonitic-alkaline volcanic associations in Superior Province. This approach is justified, in our opinion, because (1) the Timiskaming volcanics and 
examined shoshonites bear essentially similar geochemical signatures as shown later, (2) they both formed in the late Archean age $(\sim 2.7 \mathrm{Ga})$ in the same Superior Province, and hence (3) their origins could be analogous each other in the principal framework.

The origin and tectonic settings of the Timiskaming alkaline volcanic rocks have been the subject of much speculation. For example, their geochemical signature suggests their origin in a mature volcanic arc (e.g., Ujike, 1985), while their $\mathrm{Nd}$ and $\mathrm{Sr}$ isotope characteristics suggest their formation in an immature island arc remote from existing continents (e.g., Basu et al., 1984; Ben Othman et al., 1990). Moreover, their origin in an extensional tectonic regime has been suggested on the basis of geochemistry of a syenitic pluton (Rowins et al., 1993) and volcano-sedimentary analyses (e.g., Mueller et al., 1994).

The studied Wabigoon shoshonites and model partial melts fall almost entirely within the lower parts of the compositional field of the Timiskaming alkaline rocks in the incompatible element abundance diagram (Fig. 5). Probably the Timiskaming alkaline magmas were generated from mantle sources previously enriched by slab-derived metasomatic agent because they show significant negative $\mathrm{Ta}$ anomalies (Fig. 5). Among them we suggest that at least those having $\mathrm{Sr} / \mathrm{Y}$ as high as (and higher than) the studied Wabigoon shoshonites (Fig. 2b) would have been derived from sources metasomatized by adakitic magmas through lower degrees of partial melting and/or stronger mantle metasomatism compared with the studied shoshonites. In the case of the Timiskaming alkaline magmas, which apparently lack any other type of contemporaneous magmatism (Capdevila et al., 1982), the adakitic mantle metasomatism would have resulted from previous magmatism. Several studies on Phanerozoic shoshonitic rocks have shown that enriched material produced by subduction-related metasomatism can exist in the mantle for substantial periods of time after subduction has ceased, and that subsequent tectonic or thermal events may then trigger further shoshonitic magma generation (e.g., Sloman, 1989; Feldstein and Lange, 1999).

Our reexamination of the pertinent analyses by Capdevila et al. (1982) indicates that most if not all volcanic rocks of the Skead Group (2701 $\pm 2 \mathrm{Ma}$; Corfu et al., 1989), Abitibi Greenstone Belt, which is spatially adjacent to and temporally preceded the Timiskaming Group (2680-2670 Ma; Corfu et al., 1991), are adakitic (Fig. 2). We consider, therefore, that Skead volcanism, which preceded Timiskaming magmatism by $20-30$ m.y., enriched the mantle wedge. This scenario meets a requirement from $\mathrm{Nd}$ and $\mathrm{Sr}$ isotopic studies that the
Timiskaming source must have been depleted in origin and enriched shortly prior to Timiskaming volcanism (e. g., Basu et al., 1984; Ben Othman et al., 1990; Hattori et al., 1996; Ayer and Dostal, 2000). It seems probable that the geochemical signature of Timiskaming alkaline rocks was ultimately inherited from the Skead magmas via the metasomatized mantle sources. We therefore conclude that the geochemical signature of the Timiskaming alkaline volcanic rocks cannot be used as a direct indicator of tectonic settings of emplacement.

\section{Conclusions}

The late Archean shoshonite magmas of the Upper Keewatin Assemblage, western Wabigoon Belt were probably derived by partial melting of mantle peridotite metasomatized by contemporaneous slab-derived adakitic magmas. We speculate by geochemical analogy that the archetypal Timiskaming alkaline magmas, Abitibi Greenstone Belt, were generated by partial melting of mantle sources previously (20-30 m.y.) enriched by adakitic volcanism of the Skead Group.

\section{Acknowledgements}

We thank M.P. Gorton for his help with XRF analysis and the Natural Sciences and Engineering Research Council of Canada for financial support. We gratefully acknowledge to Drs. Marc J. Defant, John N. Ludden and N. Tsuchiya and an anonymous reviewer of the journal for their constructive comments and suggestions on early versions of this manuscript.

\section{References}

Arth, J.G. (1976) Behaviour of trace elements during magmatic processes - A summary of theoretical models and their applications. Journal of Research of the United States Geological Survey, 4, 41-47.

Ayer, J.A. and Davis, D.W. (1997) Neoarchean evolution of differing convergent margin assemblages in the Wabigoon Subprovince: geochemical and geochronological evidence from the Lake of the Woods greenstone belt, Superior Province, Northwestern Ontario. Precambrian Research, $81,155-178$.

Ayer, J.A. and Dostal, J. (2000) Nd and Pb isotopes from the Lake of the Woods greenstone belt, northwestern Ontario: implications for mantle evolution and the formation of crust in the southern Superior Province. Canadian Journal of Earth Sciences, 37, 1677-1689.

Basu, A.R., Goodwin, A.M. and Tatsumoto, M. (1984) Sm/ $\mathrm{Nd}$ study of Archean alkalic rocks from the Superior Province of the Canadian Shield. Earth and Planetary Science Letters, 70, 40-46. 
Ben Othman, D., Arndt, N.T., White, W.M. and Jochum, K.P. (1990) Geochemistry and age of Timiskaming alkali volcanics and the Otto syenite stock, Abitibi, Ontario. Canadian Journal of Earth Sciences, 27, 1304-1311.

Blichert-Toft, J, Arndt, N.T. and Ludden, J.N. (1996) Precambrian alkaline magmatism. Lithos, 37, 97-111.

Brooks, C., Ludden, J., Pigeon, Y. and Hubregtse, J.J.M.W. (1982) Volcanism of shoshonite to high-K andesite affinity in an Archean arc environment, Oxford Lake, Manitoba. Canadian Journal of Earth Sciences, 19, 5567.

Capdevila, R., Goodwin, A.M., Ujike, O. and Gorton, M.P. (1982) Trace-element geochemistry of Archean volcanic rocks and crustal growth in southwestern Abitibi Belt, Canada. Geology, 10, 418-422.

Condie, K.C., Viljoen, M.J. and Kable, E.J.D. (1977) Effects of alteration on element distributions in Archean tholeiites from the Barberton greenstone belt, South Africa. Contributions to Mineralogy and Petrology, 64, 75-89.

Corfu, F., Krogh, T.E. and Kwok, Y.Y., Jensen, L.S. (1989) $\mathrm{U}-\mathrm{Pb}$ zircon geochronology in the southwestern Abitibi greenstone belt, Superior Province. Canadian Journal of Earth Sciences, 26, 1747-1763.

Corfu, F., Jackson, S.L. and Sutcliffe, R.H. (1991) U-Pb ages and tectonic significance of late Archaean alkalic magmatism and nonmarine sedimentation: Timiskaming Group, Southern Abitibi belt, Ontario. Canadian Journal of Earth Sciences, 28, 489-503.

Defant, M.J. and Drummond, M.S. (1990) Derivation of some modern arc magmas by melting of young subducted lithosphere. Nature, 347, 662-665.

Defant, M.J. and Kepezhinskas, P. (2001) Evidence suggests slab melting in arc magmas. EOS, 82, 65-69.

Dostal, J. and Mueller, W. (1992) Archean shoshonites from the Abitibi greenstone belt, Chibougamau (Quebec, Canada): geochemistry and tectonic setting. Journal of Volcanology and Geothermal Research, 53, 145-165.

Ewart, A. (1982) The mineralogy and petrology of TertiaryRecent Orogenic volcanic rocks: with special reference to the andesite-basaltic compositional range. In Andesites (Thorpe, R.S. Ed.). pp. 695, John Wiley \& Sons, Chichester, 25-87.

Feldstein, S.N. and Lange, R.A. (1999) Pliocene potassic magmas from the Kings River region, Sierra Nevada, California: evidence for melting of a subduction-modified mantle. Journal of Petrology, 40, 1301-1320.

Green, T.H., Blundy, J.D., Adam, J. and Yaxley, G.M. (2000) SIMS determination of trace element partition coefficients between garnet, clinopyroxene and hydrous basaltic liquids at $2-7.5 \mathrm{GPa}$ and $1080-1200^{\circ} \mathrm{C}$. Lithos, 53, 165-187.

Hattori, K., Hart, S.R. and Shimizu, N. (1996) Melt and source mantle compositions in the Late Archaean: A study of strontium and neodymium isotope and trace elements in clinopyroxene from shoshonitic alkaline rocks. Geochimica et Cosmochimica Acta, 60, 4551-4562.

Jahn, B.M., Glikson, A.Y., Peucat, J.J. and Hickman, A.H. (1981) REE geochemistry and isotopic data of Archean silicic volcanics and granitoids from the Pilbara Block, Western Australia: implications for the early crustal evolution. Geochimica et Cosmochimica Acta, 45, 1633-1652.

Kakubuchi, S., Nagao, T. and Nagao, K. (2000) K-Ar ages and magmatic history of the Abu Monogenetic Volcano
Group, southwest Japan. Japanese Magazine of Mineralogical and Petrological Sciences, 29, 191-198 (in Japanese with English abstract).

Kelemen, P.B., Shimizu, N. and Dunn, T. (1993) Relative depletion of niobium in some arc magmas and the continental crust: Partitioning of $\mathrm{K}, \mathrm{Nb}, \mathrm{La}$ and $\mathrm{Ce}$ during melt/rock reaction in the upper mantle. Earth and Planetary Science Letters, 120, 111-134.

Kerrich, R. and Watson, G.P. (1984) The Macassa mine Archean lode gold deposit, Kirkland Lake, Ontario: Geology, patterns of alteration, and hydrothermal regimes. Economic Geology, 79, 1104-1130.

Le Maitre, R.W. (1989) A classification of igneous rocks and glossary of terms; recommendations of the international union of geological sciences subcommission on the systematics of igneous rocks. pp. 193, Blackwell. Oxford.

Martin, H. (1986) Effect of steeper Archean geothermal gradient on geochemistry of subduction zone magmas. Geology, 14, 753-756.

Martin, H. (1999) Adakitic magmas: modern analogues of Archaean granitoids. Lithos, 46, 411-429.

Maury, R.C., Defant, M.J. and Joron, J.-L. (1992) Metasomatism of the sub-arc mantle inferred from trace elements in Philippine xenoliths. Nature, 360, 661-663.

Mueller, W., Donaldson, A. and Doucet, P. (1994) Volcanic and tectono-plutonic influences on sedimentation in the Archean Kirkland Basin, Abitibi greenstone belt, Canada. Precambrian Research, 68, 201-230.

Pearce, J.A. (1983) Role of sub-continental lithosphere in magma genesis at active continental margins. In Continental basalts and mantle xenoliths (Hawkesworth, C.J. and Norry, M.J. Eds.). pp. 272, Shiva, Nantwich, 230-249.

Pearce, J.A., Alabaster, T., Shelton, A.W. and Searle, M.P. (1981) The Oman ophiolite as a Cretaceous arc-basin complex: evidence and implications. Philosophical Transactions of the Royal Society of London, series A, 300, 299-317.

Rapp R.P., Shimizu, N., Norman, M.D. and Applegate, G.S. (1999) Reaction between slab-derived melts and peridotite in the mantle wedge: experimental constraints at 3.8 GPa. Chemical Geology, 160, 335-356.

Rowins, S.M., Cameron, E.M., Lalonde, A.E. and Ernst, R.E. (1993) Petrogenesis of the Late Archean syenitic Murdock Creek pluton, Kirkland Lake, Ontario: evidence for an extension tectonic setting. Canadian Mineralogist, 31, 219-244.

Sajona, F.G., Maury, R.C., Prouteau, G., Cotten, J., Schiano, P., Bellon, H. and Fontaine, L. (2000) Slab melt as metasomatic agent in island arc magma mantle sources, Negros and Batan. The Island Arc, 9, 472-486.

Sloman, L.E. (1989) Triassic shoshonites from the Dolomites, northern Italy: alkaline arc rocks in a strike-slip setting. Journal of Geophysical Research, 94, 4655-4666.

Smithies, R.H. (2000) The Archaean tonalite-trondhjemitegranodiorite (TTG) series is not an analogue of Cenozoic adakite. Earth and Planetary Science Letters, 182, 115125.

Tatsumi, Y. and Koyaguchi, T. (1989) An absarokite from a phlogopite lherzolite source. Contributions to Mineralogy and Petrology, 102, 34-40.

Taylor, S.R. and Gorton, M.P. (1977) Geochemical application of spark source mass spectrography, III. Element 
sensitivity, precision and accuracy. Geochimica et Cosmochimica Acta, 41, 1375-1380.

Ujike, O. (1985) Geochemistry of Archean alkalic volcanic rocks from the Crystal Lake area, east of Kirkland Lake, Ontario, Canada. Earth and Planetary Science Letters, 73, 333-344.

Ujike, O. and Goodwin, A.M. (1987) Geochemistry and origin of Archean felsic metavolcanic rocks, central Noranda area, Quebec, Canada. Canadian Journal of Earth Sciences, 24, 2551-2567.

Winchester, J.A. and Floyd, P.A. (1977) Geochemical discrimination of different magma series and their differentiation products using immobile elements. Chemical Geology, 20, 325-343.

Wood, D.A., Joron, J.-L., Treuil, M., Norry, M. and Tarney, J. (1979) Elemental and $\mathrm{Sr}$ isotopic variations in basic lavas from Iceland and the surrounding ocean floor: the nature of mantle source inhomogeneities. Contributions to Mineralogy and Petrology, 70, 319-339.

Wyllie, P.J. and Sekine (1982) The formation of mantle phlogopite in subduction zone hybridization. Contributions to Mineralogy and Petrology, 79, 375-380.

Wyman, D.A., Ayer, J.A. and Devaney, J.R. (2000) Niobium -enriched basalts from the Wabigoon subprovince, Canada: evidence for adakitic metasomatism above an Archean subduction zone. Earth and Planetary Science Letters, 179, 21-30.

Yogodzinski, G.M., Kay, R.W., Volynets, O.N., Koloskov, A.V. and Kay, S.M (1995) Magnesian andesite in the western Aleutian Komandorsky region: Implications for slab melting and processes in the mantle wedge. Geological Society of America Bulletin, 107, 505-519.

Manuscript received; 11 October, 2001

Manuscript accepted; 11 November, 2002 